\title{
USE OF ANTIOPRESSIVE APPROACH IN CZECH SOCIAL WORK WITH HOMELESS PEOPLE
}

\author{
Kateřina Glumbíková, ${ }^{1}$ Alice Gojová, ${ }^{2}$ Soňa Vávrová ${ }^{3}$
}

\begin{abstract}
The article deals with the use of an anti-oppressive approach in Czech social work focused on homeless people. The theoretical part, among others, looks into the intersectionality of oppression with homeless people. This contribution also presents partial results from two research studies focused on the reflection of oppression by homeless people. The results show that oppression is perceived as pervasive and interconnected by homeless people. Intrinsically, it forms a barrier in the process of their reintegration into permanent housing forms and a barrier to their access to health services. The necessity of applying the anti-oppressive approach in Czech social work can be clearly deduced from the obtained outcomes. Specifically, its individual instruments such as the production of counter-narratives to oppressive metanarratives, advocacy, critical reflection, and agency.
\end{abstract}

UDC Classification: 304; DOI: http://dx.doi.org/10.12955/cbup.v5.994

Keywords: homelessness, intersectionality of oppression, antioppressive social work

\section{Introduction}

In the presented study, we first reflect upon three levels determining the applied approaches of Czech social work with homeless people. The expectations of society that social work will primarily be tool of control of clients and individualization of their problems form the first level (Sirovátka \& Winkler, 2010). Legislative changes, related to the fact that on March 8, 2017 the Czech Government approved a draft law on social housing and a housing allowance (Government of the Czech Republic, 2017), represent the second level. Other forthcoming legislative changes are the changes in the Social Services Act No. 108/2006 Coll., that will impose a new obligation to provide social and therapeutic service in shelters for homeless people. The third level consists of a persistent negative view of homeless people by the society. In the context of the third level, the fact that the society shares the view that homeless people are weak, lazy, handicapped and prone to psychological and social problems can be pointed out (Swick, 2005). Given the above mentioned facts, in our article we aim to present research-based arguments for the wider use of an anti-oppressive approach in Czech social work with homeless people because in this approach we see an improvement and the uplifting of social work with the target group.

\section{Theoretical basis}

Within the theoretical foundations, we proceed from the fact that identity of each individual is constructed socially (through relationships and interactions with the social environment) (Výrost \& Slaměník, 2011), both in their interpersonal form (formed by social affiliation, membership of a particular category of people ...) and in their personal form (self-identification, self-image ...). Harré \& van Langenhove (2010), who describe the existence of collectively developed "personal constructs" in which each individual is classified, speak about the mechanism of identity construction through sociality. Personal constructs are also described by Becker (1997) in his theory of "identity of outsiders" or Tajfel (1981) in his conception of in-group and out-group. Under the above mentioned situation, (forced) identification occurs, which can be explained by Cooley's theory of "mirror self," which affects the formation of the human "I" through mirroring of others' opinions of ourselves (O'Brien, 2011). In accordance with the above mentioned oppression can be understood as the exercising of power or authority of the majority group on the basis of socially and culturally constructed differences. The result is the birth of social inequality. Oppression is therefore structural in nature (Graham \& Schiele, 2010) and an individual identity is produced through it.

Lots of socially constructed forms of oppression are the basis for creation of an individual identity. An example might be the creation of "subjectivity" of single mothers in a shelter constructed mutually by reinforcing vectors of sex (gender and the situation of maternity and single parent status), race (possibly affiliation with the Roma ethnic group), class membership (the situation of homelessness and resulting socio-economic situation) and other axes of social differences or dimensions of life situations

\footnotetext{
${ }^{1}$ Faculty of Social Studies, University of Ostrava, katerina.glumbikova@osu.cz

${ }^{2}$ Faculty of Social Studies, University of Ostrava, alice.gojova@osu.cz

${ }^{3}$ Faculty of Social Studies, University of Ostrava, sona.vavrova@osu.cz
} 
(Nash, 2008). Another example might be the creation of "subjectivity" of men in shelters when their subjectivity can be formed again by class membership and race, but also by other axes such as their possible experience with the use of drugs or alcohol; or long-term poor health as a result of staying on the street. Their life situation and lived experience cannot be understood through experience with only one form of oppression, for their understanding, the interaction of all experience with oppression is important; their intersectionality. The anti-oppressive approach in social work, whose overarching principle is critical social work, is focused on intersectionality (interconnection/intersection) of various forms of oppression (Graham \& Schiele, 2010). Intersectionality becomes not only a point of interest but also an analytical tool aiming at the crossing and multidimensional power relationships for antioppressive social work (Grillo, 2013). In fact, any form of oppression is not and cannot be considered less important in anti-oppressive social work (Graham \& Schiele, 2010). The anti-oppressive approach is frequently used in foreign practice with homeless people (Gerson, 2007), while in Czech social work only a minimum of contributions dealing with this approach can be found.

\section{Research methodology}

The data presented were partial outcomes of two research studies. Our aim was to determine how homeless people reflect oppression in their replies. (1) The first research study was aimed at analyzing the perception of barriers and accelerators of the reintegration process of homeless mothers with experience of staying in a shelter into permanent forms of housing. (2) The second research study focused on understanding the health by the residents of shelters and their perception of access to health services ${ }^{4}$. Both research studies were carried out using qualitative research strategies and techniques of data collection from half-structured interviews with homeless people.

(1) The first research study was a participatory study by its nature. It was carried out with the direct collaboration of two homeless mothers changing stays in shelters that participated in all phases of the research study, from the construction of the half-structured interview, through the collection of data to their analysis. The informants were selected using stratified sampling through the institution of shelters in Ostrava. In total, 33 interviews were carried out with three groups of informants, mothers changing stays in shelters (18), mothers leaving shelters (8) and mothers reintegrated into permanent housing for at least 18 months (5). The data obtained from individual interviews were also validated in this research study using six focus groups (2) The second research study, focused on the perception of health by the residents of shelters. It was attended by 18 informants, including 8 women and 10 men from shelters from several regions of the Czech Republic (the Moravian and Zlín region and the City of Prague). The informants were selected using stratified sampling with the help of the institution of the shelter (according to individual target groups from shelters: men, women, mothers with children). The data from both research studies were recorded with the consent of participants, processed (transcribed) and subsequently analysed using the constructivist approach to the grounded theory, which assumes the existence of multiple possible realities and the construction of a new reality in the process of interaction of the researcher's reality and the reality of the participants of the research (Charmaz, 2006). Within the realization of both studies we followed the ethical principles for research involving humans (American Psychological Association, 2010).

\section{Research results and their interpretation ${ }^{5}$}

Ad (1/first research study) Interviewed homeless mothers described their living situation/experience through multiple forms of oppression. Among the most common labels that the informants referred to, were "homeless", "bad mother", "unable to take care" (in this case, for themselves and the baby), "sneak thief", "scum", "gypsy", "the one who needs to live in shelter", "black sheep of the family". In their narratives, the informants regard the oppression, which is characteristic by its ubiquity, as a barrier to the process of reintegration into permanent forms of housing; they meet with it at school: "I seemed to me that our teacher had thought that when a child was from a shelter, he/she was just stupid

\footnotetext{
${ }^{4}$ It is the project called Health of Occupants of Shelters, that Ostrava University carries out for the Association of Shelters in the Czech Republic, r.a. within the project called Development of Services for Homeless People under the Roof. Project registration number is CZ.03.2.63/0.0/0.0/99_041 /0,002,242th.

${ }^{5}$ In the following text, we denote the authentic statements with letter abbreviations of the informant and the number of the paragraph where they can be found in the transcribed text, both in brackets, to anonymize them.
} 
and would hurt other kids or I don't know ..." (KP156); at the doctor: "Some doctors, I think, look at me in a bad way because I live in a shelter ... I told it to the nurse and they told each other, I think ... since then they have been looking at me in a weird way... they keep asking what and how I eat ... once even if I have enough food ... I feel like being questioned ... I really wouldn't go there if I didn't have to " (PV1); in a shop: "Well, when you go to a shop ... they take a look at you ... and then they follow you all the time ... quietly and inconspicuously and check if you don't shoplift ... they even follow the kids " (KPR30); at authorities: "And I guess that when you go to the authority, they don't tell you everything purposely ... or they say it in the way that you don't understand it, and then you don't want to ask not to be a complete idiot..." (PV2); with flat owners: "I don't give a damn ... well everyone sees just a gypsy ... even if I had the money, I wouldn't get a flat ... Well, I've dealt with the fact that I spend the rest of my life in a shelter..." (KP7); in a shelter: "It seems to me that we're like their (ed. authors: social workers at the shelter) subjects that we have to beg for everything ... it's not possible to talk with them normally, I don't trust them at all" (KP16). "When I speak with her (ed. authors: a social worker at the shelter), I feel like being incapable ..." (KP15). Within the relationship with social workers at the shelter, the informants describe the need for understanding their life situation: "She can't even empathize with me, it was my daughter's birthday, I wanted to buy her a present, we have to hand in the money to them, you know, well, so I wanted to draw it out and she told me that she wouldn't give the money to me, that I had to save money, I tried to explain that I needed to buy a present for my daughter ... she didn't give me anything " (KP1). "They can't empathize at all, I think they can't imagine the situation we are in ..." (KP3); the establishment of trust and informal sharing "The setting of the rules here is a crap ... I wonder if they can ever want this stuff from us ... instead of asking you how you are, they just want the bills for everything you've bought this month because you're short of money, it's not possible not to be short of money and you have asked them for lentils ..." (KP3); and to reduce the social distance in the sense of "us and them": "When we go to see them, they're locked, we have to knock or ring, we can only be here in the bedroom when we want, the hours in common room are also set..." (KP19). In this context the informants reflected that a social worker is an employee of the shelter and certain work obligations and rules, that they must observe, derive from that fact: "I think that it is sometimes also hard for them ... they have to watch you here, take care and their boss probably assesses them by some tables, or not? ... they perceive that the relationship between us isn't good, as well and they also don't know what to do about it ... or the boss forces them to treat us in this way" (PV2). The informants also described the oppression against shelters as facilities for homeless people. "And I was afraid to go there because I had heard it was like a jail" (KP20). "People usually don't know what a shelter is, they think that it is a punishment, not that it has to help us ... I myself didn't know that there was something like that ... a lot of people probably don't know until they begin to stay there ..." (PV2).

Ad (2/second research study) In the second research study, the intersectionality of oppression was perceived as a barrier of the access to medical care by the informants. This barrier was interpreted as very strong, sometimes stronger than the reduced availability of health care in the sense of the absence of its low-threshold in the form of its distance and charges for medical service and medicines. "Well, now we have to treat him, well, someone unshaven, dirty, I believe that they think like that, and I'm not surprised, because when a person is somewhere under the bridge or so, I understand the doctors that they ponder it like that. If they do, but they probably do." (KPM2 $\left.{ }^{7}\right)$. "I had an inflammation of testicles, I couldn't walk. I had the money, so I went to the emergency on Saturday. The doctor even didn't come out, only the nurse in the door, she asked what I wanted, I told her my problem. She said she would ask the doctor and she came back in 10 minutes and said that the doctor advised me to go to the surgery department " (KPM1). "I have a bad experience, such a strange behavior I don't like it from them ... it seems to me that they think that you're O.K. and swing the lead. Mainly at those emergencies... I've been in the hospital a few times, and such a strange behavior. It's not; it's not right" (KPM6). "You see it's like... I don't blame the doctors that they look at you in that way" (KPM8). This perceived oppression led the informants to not take advantage of health services, or to use them only in emergency cases, which does not provide the possibility of early intervention in case of health

\footnotetext{
${ }^{6}$ Shortcuts: KP $1-33$ - communication partner and number $(1-33)$, PV $1-2$ - peer researcher and number $(1-2)$.

${ }^{7}$ Shortcuts: KP M 1 - 18 - male communication partner and number $(1-18)$, KP 1 - 18 - female communication partner and number $1-18$.
} 
problems and it is costly. "I didn't see the doctors until I ended up in the emergency room because of my stomach ... I didn't see them because I knew exactly what they would think of me ... that I was a dirt and it's my fault" (KP9). "To see the doctor only in the worst case, we prefer going to the emergency, we don't have a doctor ..." (KP3). As KP3 describes, non-use of medical assistance is associated with emergency visits.

\section{Conclusion}

The results of the presented research studies clearly show that the life experience of homeless people is associated with the interaction of several forms of oppression that are perceived as pervasive. This shows that the intersectionality of oppression is a very important analytical tool through which we can understand the life experience of homeless people. According to the informants, the intersectionality of oppression is a barrier in the process of reintegration into permanent housing and a barrier to their access to health services. The status of "disadvantaged" / "disenabled" is attributed to homeless people on the basis of oppressive metanarrative, socially shared understanding. Therefore, anti-oppressive social work may be beneficial to the services with homeless people not only because it enables us to understand their life situation, but also because it allows us to change it. Actually, the aim of antioppressive social work is to replace oppressive and controlling relationships with new relations based on equality (Dominelli, 2010). Emphasis on differences, diversity and inclusion are getting into the centre of attention (Brown, 2012). The tool of anti-oppressive social work is the production of counternarratives that are formed to oppressive metanarratives, and that may be the source of empowerment for oppressed groups and through them also for individuals (Baldwin, 2013). Another tool of antioppressive social work is Social Advocacy ("advocacy") within the meaning of defence of the rights of beneficiaries of social work, both in the broad sense, thus assertion of the rights of whole groups of disadvantaged to the public, and in the narrower sense as an assertion of the rights of specific people at different system levels (Dominelli, 2010). The right to housing for homeless people, the right to provide clear information at authorities or the right to be treated with dignity in health care facilities can be defended through this tool. In relation to the oppression perceived by social workers, the antioppressive approach can contribute to social work with the homeless people with its emphasis on critical reflection, which always asks where our knowledge comes from (Fook \& Gardner, 2007). Healy (2000) states that even social workers can contribute to reproductive oppression, and therefore they should permanently reflect not only their presumptions while working with clients, but also their personal construction about the nature of the world (Fook \& Gardner, 2007).

Based on the experience with participatory research approach, we can also point to the "action" ("agency"), which is another tool of anti-oppressive social work to achieve social change. The recipients of social work are seen as actors, as possible bearers of change that takes place through their individual and collective actions (Fook \& Gardner, 2007).

\section{References}

Act no. 108/2006 Coll., on Social Services.

American Psychological Association. (2010). Ethical principles of psychologists and code of conduct. Retrieved March, 10, 2017, from: http://www.apa.org/ethics/code/

Baldwin, C. (2013). Narrative social work: theory and application. Bristol: Policy Press.

Becker, H. (1997). Outsiders: Studies in sociology of deviance. New York: The Free Press.

Brown, M. (2012). Gender and sexuality I: Intersectional anxieties. Progress in Human Geography, 36(4), 541-550.

Charmaz, K. (2006). Constructing grounded theory: A practical guide through qualitative analysis. London: Sage.

Dominelli, L (2010). Social work in a globalizing word. Cambrigde, Malden: Polity Press.

Fook, J., \& Gardner, F. (2007). Practising critical reflection. Maidenhead: Open University Press.

Gerson, J. (2007). Hope springs maternal: Homeless mothers talk about making sense of adversity. New York: Gordian Knot Books.

Government of the Czech Republic (2017). Výsledky jednání vlády, 8. března, 2017 [The Results of Government Meeting, March 8, 2017]. Retrieved March, 10, 2017, from https://www.vlada.cz/cz/media-centrum/tiskove-zpravy/vysledky-jednanivlady-8--brezna-2017-154195/

Graham, M., \& Schiele, J. H. (2010). Equality-of-oppressions and antidiscriminatory models in social work: Reflections from the USA and UK. European Journal of Social Work, 13(2), 231-244.

Grillo, T. (2013). Anti-essentialism and intersectionality: Tools to dismantle the master's house. Berkeley Journal of Gender, Law \& Justice, 10(1), 16-30. 
Harré, H. R, \& van Langenhove E. L. (2010). People and societies. London: Routledge.

Healy, K. (2000). Social work practices. Contemporary perspectives on change. London: SAGE Publications.

Nash, J. C. (2008). Rethinking intersectionality. Feminist Review, 89, 1-15.

O'Brien, J. (2011). The production of reality: essays and readings on social interaction. Washington: SAGE Publications.

Sirovátka, T., \& Winkler, J. (2010). Nová sociální rizika [New social risks]. Sociální studia, 1, 135-156.

Swick, K. (2005). Helping homeless families overcome barriers to successful functioning. Early Childhood Education Journal, 33(3), 195-200.

Tajfel, H. (1981). Human groups and social categories: Studies in social psychology. Cambridge: Cambridge University Press.

Výrost, J., \& Slaměník, I. (2011). Sociální psychologie [Social psychology]. Praha: Grada. 